\title{
DENSITY AND DISTRIBUTION OF ENSET ROOT MEALYBUGS ON ENSET
}

\author{
TEMESGEN ADDIS, FERDU AZEREFEGNE ${ }^{1}$ and G. BLOMME ${ }^{2}$ \\ Southern Agricultural Research Institute (SARI), Awassa Research Center, P. O. Box 06, Awassa, Ethiopia \\ ${ }^{1}$ Hawassa University, Awassa College of Agriculture, P. O. Box 05, Awassa, Ethiopia \\ ${ }^{2}$ Bioversity International Uganda office. P. O. Box 24384, Kampala, Uganda
}

\begin{abstract}
The enset root mealybug (Cataenococcus ensete Williams and Matile-Ferrero) has become the most important insect pest of enset (Ensete ventricosum) in southern Ethiopia. The objective of this study was to determine the distribution and density of enset root mealybugs on enset plants. The distribution of the enset root mealybug on enset roots and corms of the 'Genticha' clone was studied in 2005 on farmers' field at Yirgachefe, southern Ethiopia. An average of 87 adult enset root mealybugs were collected from roots and corms per plant. The majority of the mealybugs inhabited the roots (79\%), while $21 \%$ was found on the corms. About $99 \%$ of the mealybugs were found in the upper $40 \mathrm{~cm}$ soil layer. In addition, about $90 \%$ of the mealybugs were collected within a $60 \mathrm{~cm}$ radius from the plants. The majority of the mealybugs (59\%) were found on the upper half of the corm. About $63 \%$ of all mealybugs were collected from the corm and on the roots within a $20 \mathrm{~cm}$ radius from the corm. Both root and shoot fresh weight had a negative correlation $\left(r^{2}=0.58\right.$ and 0.92 , respectively $)$ with the enset root mealybug population density.
\end{abstract}

Key Words: Cataenococcus ensete, corm, Ensete ventricosum

\section{RÉSUMÉ}

L'enset mealybug de racine (Cataenococcus ensete Williams et Matile-Ferrero) est devenu la peste de l'insecte le plus important d'enset (Ensete ventricosum) dans le Sud d'Ethiopie. L'objectif de cette étude était de déterminer la distribution et la densité d'enset mealybugs de racine sur les plantes d'enset. La distribution de l'enset mealybug sur les racines d'enset et les bulbes du clone de « Genticha » a été étudiée dans 2005 sur les agriculteurs > le champ à Yirgachefe, le Sud d'Ethiopie. Une moyenne de 87 enset adulte mealybugs de racine a été recueilli des racines et des bulbes par la plante. La majorité du mealybugs a habité les racines (79\%), pendant que 21\% a été trouvé sur les bulbes. Environ 99\% du mealybugs ont été trouvé dans la couche du sol de $40 \mathrm{~cm}$. Par ailleurs, environ 90\% du mealybugs ont été recueilli dans un rayon de $60 \mathrm{~cm}$ des plantes. La majorité du mealybugs (59\%) ont été trouvé sur le moitié supérieure du bulbe. Environ 63\% de tout mealybugs ont été recueilli du bulbe et sur les racines dans un rayon de $20 \mathrm{~cm}$ du bulbe. Le poids frais de la racine et des rejetons a une corrélation négative $\left(r^{2}=-0.76\right.$ et -0.96 , respectivement) avec l'enset la densité de population de mealybug de racines.

Mots Clés: Cataenococcus ensete, le bulbe, Ensete ventricosum

\section{INTRODUCTION}

Presently, more than 12 million people in Ethiopia depend on enset as a source of food (Belhu, 1991). Its production is strongly intermingled with the economic, cultural and social life of the people in enset growing regions. However, the sustainability of enset-based agriculture is threatened by a number of factors. The main biotic stresses are bacterial wilt, the enset root mealybug, nematodes, fungi and other vertebrate pests like mole rats (Quimio and Tessera, 1996; 
Brandt et al., 1997; Bogale et al., 2004; Addis, 2005). Decline in soil fertility is also rampant in many enset and banana growing regions (Kena, 1996).

The enset root mealybug (Cataenococcus ensete Williams and Matile-Ferrero, 1999) is a major pest in the enset growing regions of southern Ethiopia. It was first reported in Wonago, Ethiopia in 1988 (Tsedeke, 1988). It is mainly found below 2,000 meters above sea level (masl) in mixed farming systems where fruit trees and other cash crops like coffee were grown together (Addis, 2005). Enset plants infested with mealybugs have a retarded growth and dried lateral leaves. The insects attack all plant age groups but symptoms are more severe on 2 to 4 years old enset plants (Anonymous, 2000). Enset root mealybugs are found on roots and corms. However, during periods of extreme drought the mealybugs tend to move towards the corm when some of the roots dry out and die (Anonymous, 2001; Addis, 2005).

The enset root mealybug has 3 nymphal stages. The development of nymph to adult mealybug takes 54 days on average and the life duration of the adult root mealybug is 50 days (Addis, 2005). The total life span of the enset root mealybug is $94-113$ days and the adults are viviparous and produce 156-383 nymphs. There is generation overlap. The dispersal mechanism of enset root mealybugs is facilitated by movement of infested suckers, farm implements during cultivation, repeated transplanting operations and association with ants (Addis, 2005).

Although attempts have been made to control the enset root mealybugs by the Awassa Agricultural Research Center, cost effective and user-friendly control measures have not yet been developed (Tadesse, 2006). Among the insecticides tested, Chloropyrifos (Phyrinex 48 $\%$ ) and Diazinon 60\% EC, showed promising results for its control and eradication (Bekele, 2001; Tadesse, 2006). The effect of different amounts of farmyard manure on the incidence of the enset root mealybug was also assessed (Anonymous, 2002). The highest applied amount (20 kg plant ${ }^{-1}$ year $^{-1}$ ) resulted in vigorously growing plants with lower population numbers of enset root mealybugs. Repeated ploughing and sanitation of enset fields has also been reported as a control option for reducing enset root mealybug population numbers (Tadesse et al., 2003).

Early infestations by root mealybugs can be easily overlooked because they live underground and no visual symptoms will be observed on the above ground plant parts until extensive damage has been made to the roots and corm (Hara et al., 2001).

Digging and uprooting the whole plant to assess the enset root mealybugs is destructive, tedious and time consuming. This is due to a lack of knowledge on the distribution of the mealybugs on the root system and corm. Assessing the density and distribution of the enset root mealybugs in relation to the corm and roots would enable fine-tuning of sampling protocols and the development of a (partially) non-destructive assessment method.

\section{MATERIALS AND METHODS}

The distribution and density of the enset root mealybug on enset roots and corms was studied in 2005 at Yirgachefe, southern Ethiopia, which is located at $38^{\circ} 12^{\prime} \mathrm{E}, 6^{\circ} 12^{\prime} \mathrm{N}$, and at 1,847 masl with an average annual rainfall of $1,211 \mathrm{~mm}$. The Yirgachefe district from the Gedeo zone was selected because this is where enset root mealybugs were found to be the most severe (Addis, 2005). In the Yirgachefe district, two adjacent farms were selected. Enset plants of the 'Genticha' clone, which is dominantly grown in the Sidama and Gedeo zones of Ethiopia, and which is susceptible to the enset root mealybug (Addis, 2005), was assessed during 2005.

Ten randomly selected three-year-old enset plants were assessed in each farmer's field. This stage of the plant has a well developed root system and is known to harbour high populations of the enset root mealybug (Anonymous, 2000). Cubes of soil and roots with a size of $20 \mathrm{~cm} \mathrm{x} 20$ $\mathrm{cm} \times 20 \mathrm{~cm}$ were dug out starting from the area adjacent to the corm, up to a distance of $80 \mathrm{~cm}$ from the corm and up to a depth of $100 \mathrm{~cm}$. Roots were carefully separated from the soil by hand picking. Cord roots and adult root mealybugs were counted for each cube. Subsequently, the complete root system was excavated to count 
the number of mealybugs on the under side of the corm and to measure the fresh weight of the corm and roots.

An additional twelve enset plants of the same age and clone were also completely excavated. For the 22 excavated plants, the following parameters were assessed: plant height (m), pseudostem circumference measured at soil level (m); leaf fresh weight $(\mathrm{kg})$, pseudostem fresh weight (kg), corm fresh weight $(\mathrm{kg})$ and root fresh weight (kg) (using a measuring balance) and number of adult mealybugs on the complete root system and corm. Correlation analysis was carried out to determine the relationships between mealybug population densities and shoot and root fresh weight for these 22 excavated plants.

The corm was equally split into two parts (upper half; i.e. 50\% corm volume and the lower half) and the number of mealybugs was recorded for each half. The $\mathrm{X}^{2}$ test was used to calculate differences in mealybug numbers among different plant parts (SPSS 12.0, 2003) using Tukey’s test.

\section{RESULTS}

Enset root mealybugs were found both on the roots and corms of the assessed enset plants (Table 1). The population density of the mealybugs was significantly $(\mathrm{P}<0.05)$ higher on the roots than the corms. On average, 87 enset root mealybugs were counted per sampled plant. For the 10 plants combined, $79 \%$ of the total mealybug population was collected from the roots whereas $21 \%$ was collected from the corm.

A slightly higher number of mealy bugs (10.7 \pm 4.96) were observed on the upper half of the corm. Enset root mealy bugs prefer to feed on newly formed cord roots and these roots are formed at the upper and youngest half of the corm (Table 1).

Enset root mealybugs were found up to a soil depth of $60 \mathrm{~cm}$ and up to $80 \mathrm{~cm}$ from the corm (Fig. $1 \mathrm{~A}$ and B). However, root density as well as mealybug population numbers decreased with increasing soil depth. About $99 \%$ of the mealybugs and $96 \%$ of the roots were collected within the upper $40 \mathrm{~cm}$ soil layer. In addition, about $90 \%$ of the mealybugs were found within a $60 \mathrm{~cm}$ radius from the plant. About $42 \%$ of the mealybug population on the root system was found adjacent to the corm.

Both root and shoot fresh weights were negatively correlated with the population density of root mealybugs ( $r^{2}=0.58$ and 0.92 , respectively) (Fig. $2 \mathrm{~A}$ and $\mathrm{B}$ ). In addition, both plant height and pseudostem circumference were negatively correlated to the population density of root mealybugs ( $r^{2}=0.66$ and 0.61 respectively) (Fig. $3 \mathrm{~A}$ and $\mathrm{B})$.

\section{DISCUSSION}

Another study on the root distribution down the soil profile assessed on 4-year-old domesticated enset plants showed that the root density decreases with increasing soil depth. About 89 and 96\% of cord roots of 'Yeka' and 'Mashagamo' enset plants were found within the upper $40 \mathrm{~cm}$ soil layer, respectively (Blomme et al., in press).

Several studies conducted on the Musa spp. root system indicated that the number of cord roots (i.e. adventitious roots) varied considerably upon the health status of the plant (Summerville, 1944; Robin and Champion, 1962; Beugnon and

TABLE 1. Distribution of the Cataenococcus ensete population on corm and roots of enset plants $(n=10)$

\begin{tabular}{|c|c|c|c|}
\hline Plant part & \multicolumn{2}{|c|}{ Number of mealybugs } & SE \\
\hline Corm (total) & $18.1^{\mathrm{a}}$ & & 10.99 \\
\hline Corm (upper half) & & $10.7^{a}$ & 4.96 \\
\hline Corm (lower half) & & $7.4^{\mathrm{a}}$ & 6.42 \\
\hline Roots & $68.6^{b}$ & & 16.73 \\
\hline Total & 86.7 & 18.1 & 20.43 \\
\hline
\end{tabular}

Means followed by the same letter within a column are not significantly different according to $x^{2}$ test at $5 \%$ probability level 

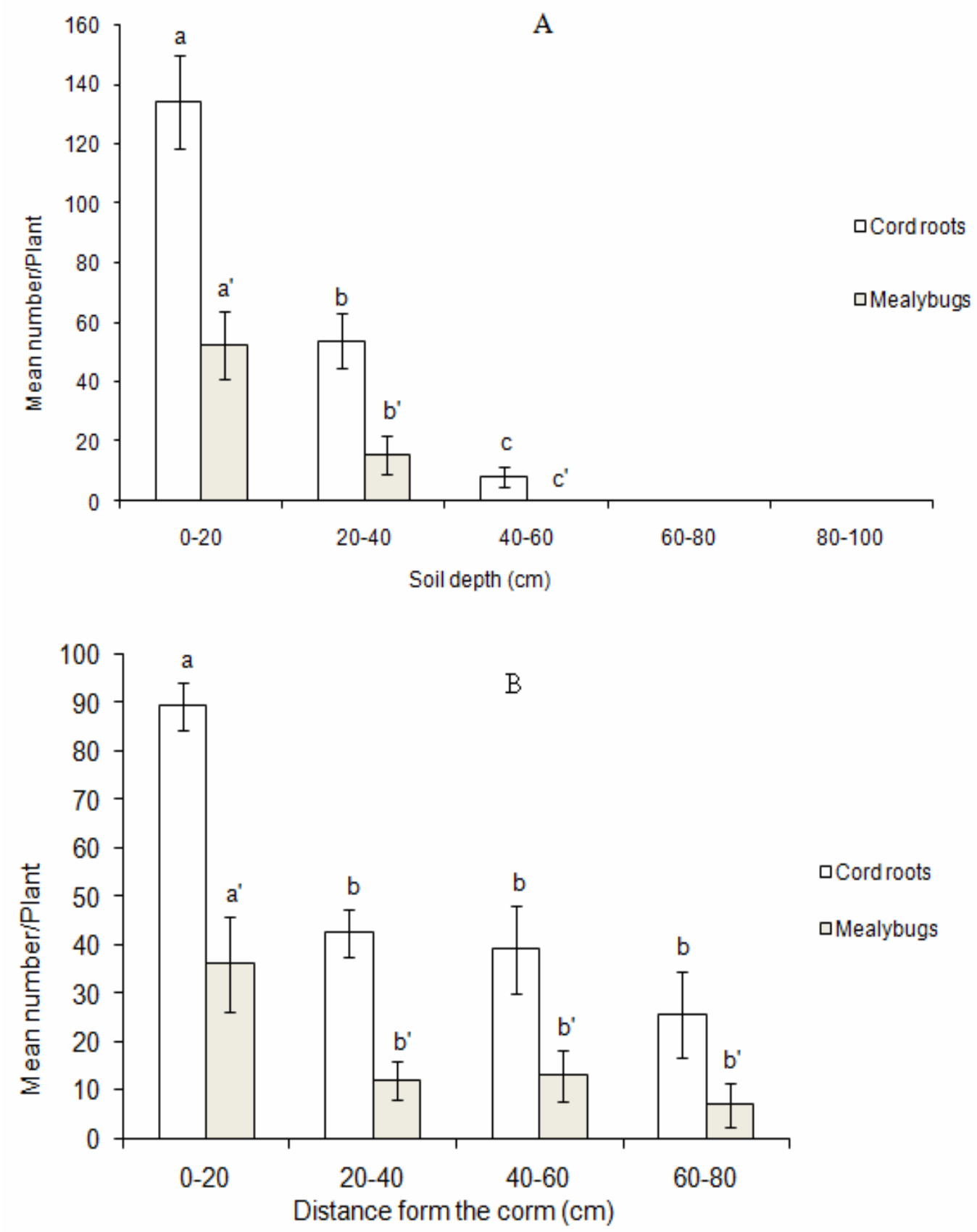

Figure 1. Vertical (A) and horizontal (B) distribution of enset cord roots and enset root mealybugs $(n=10)$. Bars followed by the same letter for cord roots and mealybugs are not significantly different according to Tukey's test at $p \leq 5 \%$.

Champion, 1966). Roots generally spread over 2 Similarly, the root distribution of Musa spp. down to $3 \mathrm{~m}$ and may extend up to $5 \mathrm{~m}$ from the plant, the soil profile was mainly limited to the upper 40 but most of the root system occurs within a 60 cm (Irizarry et al., 1981). $\mathrm{cm}$ radius from the stem (Gousseland, 1983). 
A
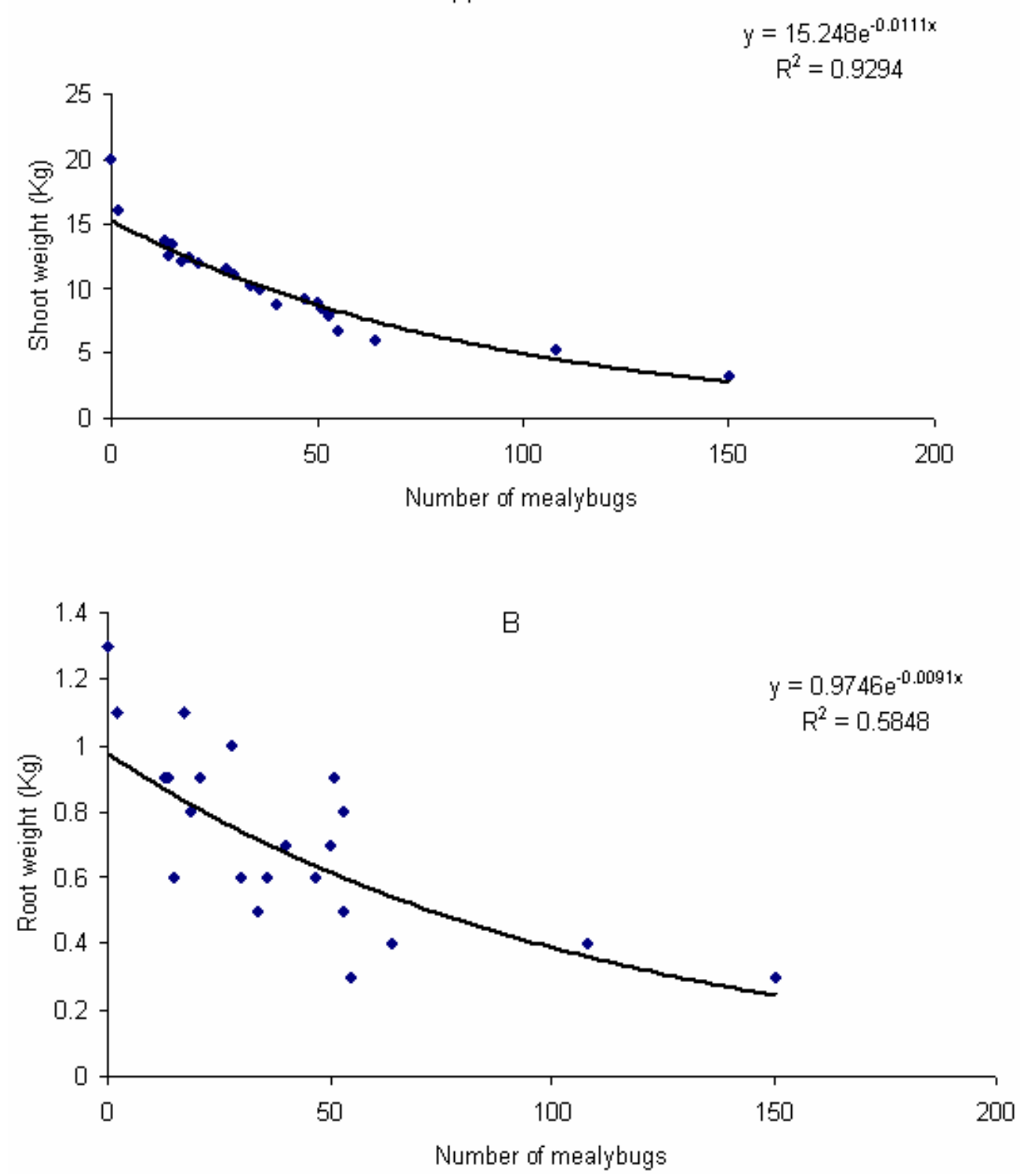

Figure 2. Relationship between enset shoot fresh weight [i.e. leaf + corm + pseudostem fresh weight] (A) and root fresh weight (B) with the enset root mealybug population number $(n=22)$.

Most of the mealybugs were found within a $20 \mathrm{~cm}$ radius from the corm possibly because mealybugs prefer to feed on newly formed roots due to their sap sucking feeding habit. Jansen (1994) observed that root mealybugs of cassava particularly feed on the new roots in the upper soil layers, leading to a reduction in nutrient and water uptake.

Although no period of extreme drought was observed during the trial period, root mealybugs also prefer to stay close to the corm as some of the roots die off during periods of extreme 

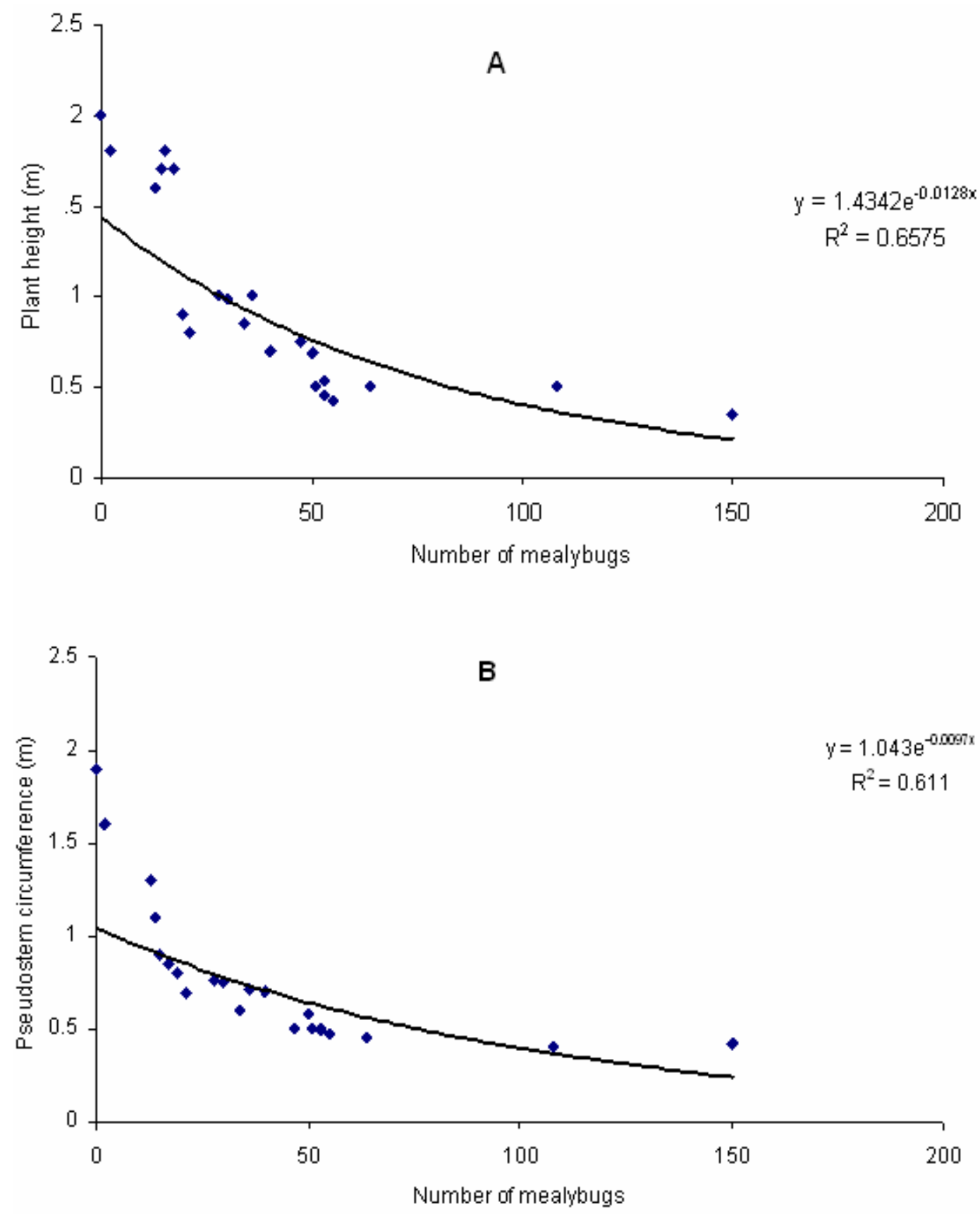

Figure 3. Relationship between enset plant height $(A)$ and pseudostem circumference measured at soil level $(B)$ with the enset root mealybug population number $(n=22)$.

drought. The corm surface may then become the main feeding area. A slow down in plant growth during the dry season may be accelerated by the mealybug infestation. Brandt et al. (1997) indicated that the damage of enset root mealybugs appeared more severe during the dry season. In addition, Ngeve (2003) also mentioned 
that the cassava root mealybugs' impact was higher during the dry season.

Addis (2005) observed that enset plants attacked by enset root mealybugs had fewer cord roots than the healthy plants. In addition, infested young enset plants were easily uprooted at the time of assessment. Brouwer (1963) reported that there is a functional equilibrium between the growth of the shoot and the root. Hence, a significant stress in either the shoot or the root system will induce responses throughout the plant. This was indeed observed in the present study, where a reduction in root and corm health due to enset root mealybugs resulted in a less vigorous above ground plant growth.

\section{CONCLUSIONS}

Most of the enset root mealybugs are found within a $20 \mathrm{~cm}$ radius from the corm. Hence, sampling a 20 × 20 x $20 \mathrm{~cm}$ cube of soil and roots adjacent to the corm will capture a large part of the mealybug population. In addition, several plants should be uprooted to assess population densities on the corm surface especially during the dry season when mealybugs move to the corm surface due to root drying/dying and a reduction in new root growth/initiation. Knowledge on the density and distribution of mealybugs on the enset corm and root system, generated by this study will provide field technicians and researchers with a simple tool to assess variation in population numbers of enset root mealybugs and could be a useful tool when evaluating the effects of different integrated pest management (IPM) control options on enset root mealybug population numbers or when screening large numbers of enset clones for their resistance against this insect.

\section{ACKNOWLEDGEMENTS}

The authors thank the Flemish Association for Development Co-operation and Technical Assistance (VVOB, Belgium) for financial contribution to this study.

\section{REFERENCES}

Addis, T. 2005. Biology of enset root mealybug Cataenococcus ensete and its geographical distribution in southern Ethiopia. MSc. Thesis. Alemaya University of Agriculture, School of Graduate studies. Alemaya, Ethiopia. 81 pp.

Anonymous, 2000. Awassa Agricultural Research Center Progress Report for the period 1999. Awassa, Ethiopia.

Anonymous. 2001. Awassa Agricultural Research Center progress report of Entomology research section for the year 2000. Awassa, Ethiopia. 7pp.

Anonymous. 2002. Awassa Agricultural Research Center progress report of plant protection research division for the year 2000. Awassa, Ethiopia. 46 pp.

Bekele, T. 2001. Insecticidal screening against enset root mealybug Paraputo spp. Addis Ababa, Ethiopia. AgriTopia. News letter 16 (2): 2-3.

Belhu, T. 1991. The position of enset (Ensete ventricosum) research in Ethiopia. pp. 29-32 . In proceedings of the regional advisory committee meeting. INIBAP, Regional Network for eastern Africa.

Beugnon, M. and Champion, J. 1966. Etude sur les racines du bananier. Fruits 21: 309-327.

Blomme, G.., Sebuwufu, G., Turyagyenda F.L. and Addis, T. 2005. Comparison of root and shoot development in enset (Ensete ventricosum) and banana (Musa spp.) (in press).

Bogale, M., Speijer, P. R., Mekete, T., Mandefro W., Tessera M. and Gold, C. S. 2004. Survey of plant parasitic nematodes and banana weevil on Ensete ventricosum in Ethiopia. Nematologia Mediterranea 32:223-227.

Brandt, S. A., Anita, S., Clifton, H., Terrence, M.C. J., Endale, T., Mulugeta, D., Gizachew, W. M., Gebre, Y., Masyoshi, S. and Shiferaw, T. 1997. The "Tree against Hunger": Enset-based agricultural systems in Ethiopia. American Association for the Advancement of Science, Washington, DC, USA. 56 pp. 
Brouwer, R. 1963. Some aspects of the equilibrium between aboveground and underground plant parts. Jaarb. I.B.S. (Wageningen). pp. 31-39.

Gousseland, J. 1983. Etude de I'enracinement et de I'emission racinaire du bananier 'Giant Cavendish’ (Musa acuminata AAA, sousgroupe Cavendish) dans les andosols de la Guadeloupe. Fruits 38: 611-623.

Hara, A. H., Nino-Duponte, R. Y. and Jacobsen, C. M. 2001. Root mealybugs of quarantine significance in Hawaii. Cooperative Extension Service, CTAHR, university of Hawaii, Manoa. IP-6. 4 pp.

Irizarry, H., Vicente-Chandler, J. and Silva, S. 1981. Root distribution of plantains growing on five soil types. The Journal of Agriculture of the University of Puerto Rico. Vol. LXV. No.1, 29-34 pp

Jansen, M. G. M. 1994. Coccinea: Scale insects. Annual Report 1994, Diagnostic Centre, Plant Protection Service, Wageningen, The Netherlands. pp. 44-45.

Kena, K. 1996. Soil problems associated with enset production. In: Proceedings of the first international workshop on enset. T. Abate, C. Hiebsch, S. A. Brandt and S. Gebre Mariam (Eds.), pp. 271-275. 13-20 Dec 1993. Addis Ababa, Ethiopia.

Ngeve, J. M. 2003. The cassava root mealybug Stictococcus vayssierei (Richard) (Homoptera: Stictococcidae): A threat to cassava production and utilization and utilization in Cameroon. International Journal of Pest Management 49(4): 327-333.

Quimio, A. J. and Tessera, M. 1996. Diseases of enset. In: proceedings of the first international workshops on enset. Tsedeke A., Clifton H., Brandt, S.A. and Seifu G. (Eds.), pp. 188-203. 13-20 Dec 1993. Addis Ababa, Ethiopia.

Robin, J. and Champion, J. 1962. Etudes des émissions des racines de la variété du bananier Poyo. Fruits 17: 93-94.

SPSS 12.0, 2003. SPSS 12.0 for windows. Release 12.0.0 (4 Sep 2003). Copyright (C SPSS inc., 1989-2003.

Summerville, W.A.T. 1944. Studies on nutrition as qualified by development in Musa Cavendishii Lambert. Queensland Journal of Agricultural Science 1: 1-127.

Tadesse, M., Anito, E. and Geta, E. 2003. EnsetBased Farming Systems of Masha wereda, Shaka zone. EARO Research Report No. 51. Addis Ababa, Ethiopia. 25 pp.

Tadesse, E. 2006. Evaluation of some synthetic and botanical insecticides against the enset root mealybug (Cataenococcus ensete) (homoptera: pseudococcidae) William and Matile-Fererro in Southern Ethiopia. MSc thesis, Department of plant sciences, Awassa college of agriculture, School of Graduate Studies Hawassa University Awassa, Ethiopia. pp. 67.

Tsedeke, A. 1988. Insect and mite pests of horticultural and miscellaneous plants in Ethiopia. Handbook, Addis Ababa, Ethiopia. 115pp.

Williams, D. J. and Matile-Ferrero, D. 1999. A new species of the mealybug genus Cataenococcus ferris from Ethiopia on Ensete ventricosum, a plant infected by a virus (Hemiptera: Pseudococcidae; Musaceae). Revue française d'Entomologie (N.S.) 21 (4): 145-149. 